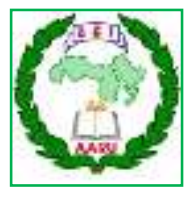

Arab Univ. J. Agric. Sci., Ain Shams Univ., Cairo, Egypt

29(1), 447 - 457, 2021

Website: http://ajs.journals.ekb.eg

DOI: 10.21608/ajs.2021.50363.1301

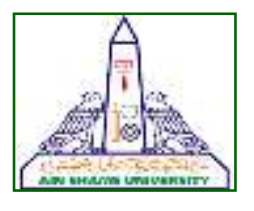

447

\title{
Efficiency of Three Bacterial Strains Against Tetranychus urticae Koch (Acari: Tetranychidae) Under Laboratory Conditions
}

\author{
Heba M Emam* \\ Plant Protection Dept, Fac. of Agric, Ain Shams Univ, P.O. Box 68, Hadayek Shoubra \\ 11241, Cairo, Egypt \\ *Corresponding author: Hebasoliman@agr.asu.edu.eg
}

Received 3 December, 2020

Accepted 28 February, 2021

\begin{abstract}
This study was conducted to evaluate the efficiency of three bacterial strains Pseudomonas aeruginosa, Bacillus subtilis and Lysinibacillus spaericus against adult females of Tetranychus urticae Koch using spraying and dipping techniques with concentrations $\left(10^{1}\right.$, $\left.10^{3}, 10^{5}, 10^{7} \mathrm{cfu} \cdot \mathrm{ml}^{-1}\right)$. The mortality percentages were calculated and numbers of each stages resulting from the live treated females were recorded. The symptoms that appear on treated female's mites as a result of death under laboratory conditions were recorded and photographed. The results revealed that, $P$. aeruginosa caused the highest mortality percentage of adult females T. urticae $100 \%$ after $72 \mathrm{~h}$ at concentration $10^{7} \mathrm{cfu}$. $\mathrm{ml}^{-1}$ by spraying application. Whereas the mortality percentage were recorded by the dipping technique was $54.58 \pm 1.71$. B. subtilis also, was recorded increased the average mortality percentage of female $T$. urticae as it reached $73.33 \pm 2.67$ in spraying technique compared $41.25 \pm 2.08$ in dipping technique. While in L. spaericus recorded $62.08 \pm 3.41$ mortality (\%) in spraying technique but at dipping technique the mortality was $27.50 \pm 1.61$. A sharp decrease was shown in number of stages resulting from lived treated females of $T$. urticae with $P$. aeruginosa by four concentrations $10^{1}, 10^{3,} 10^{5}$ and $10^{7}$ by using spraying technique and the life cy-
\end{abstract}

cle was stopped at the larval stage only at concentration $10^{1}$ and were not changed into the nymphal stage. While with dipping technique a slight increase in the average number of stages resulting from the adult living females treated with the previously aforementioned concentrations of bacteria $P$. aeruginosa. The present study cleared that application of bacteria strains on $T$. urticae adult females either by spraying or dipping techniques lead to some deformations such as, swelling of the body, then fluids exit followed by complete dryness of the body and forward protrusion of the podosoma region and finally death of the adult females.

Keywords: Tetranychus urticae; Pseudomonas aeruginosa; Bacillus subtilis; Lysinibacillus spaericus; Biological control

\section{Introduction}

The Two-Spotted Spider Mite (TSSM), Tetranychus urticae Koch (Acari: Tetranychidae), is a phytophagous mite that is distributed worldwide. This pest pierces the plant epidermis with chelicera and feeds on the cell contents, Decreasing photosynthetic efficiency. (Park and Lee 2002). The spread of the twospider mite is based on high fecundity of the females, which can lead to a quick population increase (Carey and Bradley 1982). Purpose of 
acaricides that the development of pesticideresistance strains of $T$. urticae and remains the effect problems of these pesticides (Muir and Cranham 1979). A definition of biological control (defined as): "the use of living organisms to decrease injury caused by pests and diseases to possible levels" Biological control methods have become more essential (Fiedler 2012). Biological control factors like predators, parasites, fungi or bacteria can be used for management of mites (Arzanlou et al 2016). Among these organisms, Bacteria, such as Pseudomonas entomophila, Burkholderia spp., Chromobacterium spp., Streptomyces spp., Bacillus spp. and Saccharopolyspora spp., have all recently obtained commercial benefit for production of numerous metabolites that perform as strong insecticides (Ruiu 2015). Chitinase enzymes that capable of chitin degradation existent in the cell walls of fungi and insect exoskeletons are thought to be one of the important metabolites produced by these bacteria. Thus, several pathogenic bacteria have a potential role as biological control agents for various fungal and insect pests. (Rathore and Gupta 2015). Pseudomonas species have also been shown to be effective as a biological control agent of the two-spotted spider mite pest. (Aksoy et al 2008) indicated that, Pseudomonas putida, isolated from tomato plant soils in Turkey, recorded high mortality percentage to the two-spotted spider mites. Furthermore, Pseudomonas fluorescens produces bacterial chitinases which are effective to control the mites by hydrolyzing their chitinous exoskeleton (Roobakkumar et al 2011). Strains of $B$. thuringiensis make endotoxins which are lethal to lepidopeterous, coleopeterous, dipterous insects, mites, nematodes, protozoa and fluke worms (Veloorvalappil et al 2013). Paenibacillus polymyxa, Bacillus subtilis, Bacillus cereus, Achromobacter xylosoxidans, Pseudomonas aeruginosa and Lysinibacillus sphaericus caused 100, 97.25, 94, 93, 92, $84.29 \%$ mortality of Meloidogyne incogneta after $48 \mathrm{~h}$ of treatment. (Soliman et al 2019).

\section{Materials and methods}

\subsection{Rearing of two-spotted spider mite (TSSM), T. urticae}

\subsubsection{Source of $T$. urticae}

TSSM was collected from infested tomato and cucumber leaves which are grown in the experimental greenhouse at the campus of Faculty of Agriculture, Ain Shams University, Egypt.

\subsection{Mite colony}

One newly virgin adult female was transferred by a fine camel hair brush to a sweet potato leaf disc ( $1 \mathrm{~mm}$, in diameter), preserved on a humid cotton wool pad in a Petri dish and left for a period $24-48 \mathrm{~h}$ to allow it to lay eggs. The deposited eggs were preserved under laboratory conditions at $25 \pm 2{ }^{\circ} \mathrm{C}, 60 \pm 5 \%$ R.H. and 16 $\mathrm{L}: 8 \mathrm{D}$ photoperiod until hatching. The female mite was mounted on a glass slide in Hoyer's media for identification. The recently hatched larvae were transferred singly to sweet potato fresh leaves to follow their developing (Pritam and Clare 1993).

\subsection{Bacterial strains}

Three rhizobacterial isolates originated from rhizospheric soil collected from different areas at Giza governorate, Egypt. The obtained strains were identified according to $16 \mathrm{~S}$ rRNA sequence analysis and deposited in the Gen Bank database as Lysinibacillus sphaericus (Accession No. LC215050), Bacillus subtilis (Accession No. LC215051) and Pseudomonas aeruginosa (Accession No. LC215048) were isolated by (Soliman et al 2019).

\subsubsection{Growth conditions}

Luria Broth medium (LB) was prepared of tryptone $10 \mathrm{~g}$, Yeast Extract $5 \mathrm{~g}, \mathrm{NaCl} 5 \mathrm{gL}^{-1}$. Strains were grown in complete medium for stored (Peptone $5 \mathrm{~g}$, Yeast extract $3 \mathrm{~g}$, agar 20g and distilled water $1000 \mathrm{ml}$. (Davis et al 1980). 


\subsubsection{Preparation of bacterial inoculum}

For each bacterial strain, a conical flask $(250 \mathrm{ml})$ containing $100 \mathrm{ml}$ of LB broth medium was inoculated and incubated at $28-30^{\circ} \mathrm{C}$ with shaking at $150 \mathrm{rpm}$ for $48 \mathrm{~h}$. prior to application. Each one $\mathrm{ml}$ distilled water contains $2.50 \times 10^{7}$ colony forming units $\left(\mathrm{cfu} . \mathrm{ml}^{-1}\right)$.

\subsection{Bacterial strains as bio-control agent}

Mention the names of tested bacteria were evaluated under the laboratory conditions against adult females of $T$. urticae. Twenty healthy adult females per four replicates (5 individuals of female mite/leaf disc) added in petri dish. Four concentrations of bacterial strains were prepared from the main suspension $\left(10^{1}\right.$, $\left.10^{3}, 10^{5}, 10^{7} \mathrm{cfu} . \mathrm{ml}^{-1}\right)$ in addition to another group of replicates served as a control test. Spraying and dipping application were carried on to each replicate. For spraying technique, after the mites had been placed on the leaf discs, the suspension was sprayed at a distance of $25-30 \mathrm{~cm}$ with a hand spray atomizer, replicates served as control were sprayed with distilled water. While for dipping technique, the leaf discs were dipped in each concentration $\left(10^{1}, 10^{3}, 10^{5}, 10^{7} \mathrm{cfu} . \mathrm{ml}^{-1}\right)$ for 5 seconds, then T. urticae mites were transferred to the treated leaf discs using a fine camel hair brush. Numbers of live and dead individuals were counted after 24,48 and $72 \mathrm{~h}$ of all treatments and control. In addition, number of eggs, larvae and nymphs of each concentration for both spraying and dipping application. The percentage mortality of mites was calculated by using the following formula according to (Abbott's 1925).

Recording the numbers of stages resulting from the live treated females at each concentration then recording and photographing the symptoms that appear on the treated females as a result of death due to exposure to bacteria.

\subsection{Statistical analysis}

Data of all results were analyzed according to Steel and Torrie, 1984. The means were compared by Duncan's Multiple Range Test (DMRT) at 5\% clarifying by LSD test (Duncan 1955).

\section{Results and Discussion}

\subsection{Effect of three bacterial strains against Tetranychus urticae by using spraying tech- nique.}

Data presented in Table 1 showed that, the highest mortality percentage $(100 \%)$ of adult females $T$. urticae was observed with $P$. aeruginos $a$ after $72 \mathrm{~h}$ at concentration $10^{7}$, followed by $10^{5}(95 \%)$ was recorded, then $10^{3}$ and $10^{1}$ were recorded 90 and 80 (percentage mortality) comparing with the control recorded $15 \%$ respectively, while after $24 \mathrm{~h}$, the lowest mortality percentage was recorded $55 \%$ at concentration $10^{1}$ and the general mean of the dead individuals, $82.50 \pm 1.61$ was observed compared to that of the control, $11.67 \pm 0.93$. In $B$. subtilis, after $72 \mathrm{~h}$ the highest mortality percentage of adult females was recorded $95 \%$, $85 \%$ at concentrations, $10^{7}$ and $10^{5}$ respectively followed by $80 \%$ and $75 \%$ at concentrations $10^{3}$ and $10^{1}$ respectively but also, after $24 \mathrm{~h}$, the lowest mortality percentage was recorded $(40 \%)$ at concentration $10^{1}$ and general mean of the dead individuals $73.33 \pm 2.67$ was recorded In L. spaericus, also showed high mortality percentage $(80 \%)$, at concentration $10^{7}$ after $72 \mathrm{~h}$ followed by 75,65 and $60 \%$ at $10^{5}, 10^{3}$ and $10^{1}$, respectively while after $24 \mathrm{~h}$, the lowest mortality percentage $(25 \%)$ was recorded at concentration $10^{1}$ with a general mean of the dead individuals $62.08 \pm 3.41$ was recorded in this strain. And so, the results showed highly significant differences among the three bacterial strains. Accordingly, P. aeruginosa was more effective on adult females 
Table 1. Mortality percentage of adult females Tetranychus urticae as affected by three bacterial strains by using spraying technique under laboratory conditions

\begin{tabular}{|c|c|c|c|c|c|c|c|}
\hline \multirow[t]{2}{*}{ Type of bacteria } & \multirow{2}{*}{$\begin{array}{c}\text { Con. } \\
\left(\text { cfu. } \mathbf{~ m l}^{-1}\right)\end{array}$} & \multicolumn{3}{|c|}{$\begin{array}{c}\text { \% Mortality After } \\
\text { detected hours }\end{array}$} & \multirow{2}{*}{$\begin{array}{c}\text { General } \\
\text { mean } \pm \text { S. E }\end{array}$} & \multirow[t]{2}{*}{ F. Value } & \multirow[t]{2}{*}{ L.S. D } \\
\hline & & $24 h$ & $48 \mathrm{~h}$ & $72 \mathrm{~h}$ & & & \\
\hline Control & (water only) & 10.00 & 10.00 & 15.00 & $11.67 \pm 0.93 \mathrm{~d}$ & $4.20 *$ & 3.22 \\
\hline \multirow{4}{*}{ Pseudomonas aeruginosa } & $10^{1}$ & 55.00 & 70.00 & 80.00 & \multirow{5}{*}{$82.50 \pm 1.61 \mathrm{a}$} & \multirow{5}{*}{$40.20 * *$} & \multirow{5}{*}{5.58} \\
\hline & $10^{3}$ & 65.00 & 85.00 & 90.00 & & & \\
\hline & $10^{5}$ & 80.00 & 90.00 & 95.00 & & & \\
\hline & $10^{7}$ & 85.00 & 95.00 & 100.00 & & & \\
\hline Mean & & $71.25 \mathrm{c}$ & $85.00 \mathrm{~b}$ & $91.25 \mathrm{a}$ & & & \\
\hline \multirow{4}{*}{ Bacillus subtilis } & $10^{1}$ & 40.00 & 65.00 & 75.00 & \multirow{5}{*}{$73.33 \pm 2.67 \mathrm{~b}$} & \multirow{5}{*}{$18.07 * *$} & \multirow{5}{*}{9.23} \\
\hline & $10^{3}$ & 55.00 & 70.00 & 80.00 & & & \\
\hline & $10^{5}$ & 70.00 & 75.00 & 85.00 & & & \\
\hline & $10^{7}$ & 80.00 & 90.00 & 95.00 & & & \\
\hline Mean & & $61.25 \mathrm{~b}$ & $75.00 \mathrm{a}$ & $83.75 \mathrm{a}$ & & & \\
\hline \multirow{4}{*}{ Lysinibacillus spaericus } & $10^{1}$ & 25.00 & 55.00 & 60.00 & \multirow{5}{*}{$62.08 \pm 3.41 \mathrm{c}$} & \multirow{5}{*}{$8.10 *$} & \multirow{5}{*}{11.8} \\
\hline & $10^{3}$ & 45.00 & 60.00 & 65.00 & & & \\
\hline & $10^{5}$ & 65.00 & 70.00 & 75.00 & & & \\
\hline & $10^{7}$ & 70.00 & 75.00 & 80.00 & & & \\
\hline Mean & & $51.25 \mathrm{~b}$ & $65.00 \mathrm{a}$ & $70 a$ & & & \\
\hline
\end{tabular}

Means with the same letter within each column are not significantly different at the $0.5 \%$ level (Duncan's multiple ranges clarifying by LSD test).

of $T$. urticae followed by $B$. subtilis then $L$. spaericus compared to the control and the mortality percentage increase by increasing the concentration and time period. These results are in harmony with that proved by (Mahmoud et al 2020) cleared that, the highest efficiency rate on T. urticae was observed with Acinetobacter sp. sprays. Mite mortality reached 87.15 and $77.29 \%$ under laboratory and greenhouse conditions respectively after three days of treatment. Also, after seven days of treatment the mortality percentage were significantly lowered 72.22 and $67.11 \%$ and 70.74 and $65.19 \%$ using B. subtilis and B. qassimus under laboratory and greenhouse conditions. Also, (Li et al 2019) reported that, Bacillus velezensis $\mathrm{W}_{1}$ caused mortality of $T$. urticae, and can be used as a microbial acaricide in the field and the greenhouses. In addition to (Abou Zaid et al 2018) revealed that, when the bacterial strains, Lysinibacillus sphaericus and Bacillus amyloliquefaciens sprayed on common bean plants to control T. urticae, a significant decrease in the population by $37 \%$ was observed after 3 days of the treatment so, it is possible to use these bacterial strains as bio-control agents against $T$. urticae.

Data given in Table 2 revealed that, there was a sharp decrease in the number of the stages resulting from live adult females of $T$. urticae after treatment with the first strain of bacteria $P$. aeruginosa by the four concentrations $10^{1}, 10^{3}, 10^{5}$ and $10^{7}$. Fewer numbers were recorded for egg and larval stages 1.67 and 1.33 individual at the lower concentration $10^{1}$. At $10^{3,} 10^{5}$ and $10^{7}$, no numbers were recorded for both stages. Whereas no individuals of nymph stage were recorded in any concentration. Life cycle of T. urticae has stopped at the larval stage only at concentration of $10^{1}$ and has not been transformed into the nymphl stage. The general average of the moving stages $0.17 \pm 0.23$ individual was recorded compared to that of the control, and the numbers of eggs, larvae and nymphs were 86,55 and 66 individuals respectively with general mean of moving stages was $60.50 \pm 7.72$. In the case B. subtilis, also, a decrease in numbers of 


\section{Efficiency of Three Bacterial Strains Against Tetranychus urticae Koch (Acari: Tetranychidae) Under Laboratory Conditions}

the moving stages resulting from living adult females after the treatment with the previously aforementioned concentrations was observed. At concentration $10^{1}$ and $10^{3}$ numbers of the eggs and the larvae were 6.00, 3.33 and 2.00, 1.34 individual, respectively. While at the concentrations $10^{5}$ and $10^{7}$ nothing was recorded. The general average of the moving stages 0.42 \pm 0.35 individual was recorded, while there were not any nymphs resulted at the all concentrations compared to control. The third tested strain, L. spaericus recorded a slight increase in the numbers of the stages compared with ( $P$. aeruginosa and B. subtilis). The average number of stages recorded for each of the egg, larva and nymph stages at the lowest concentration $10^{1}$ was $8.67,3.66$ and 2.66 individual, respectively. While, in the highest concentration, $10^{7}$ no individuals of any stage were recorded. The data cleared that, $L$. spaericus gave a little effect to some extent when compared to $P$. aeruginosa and $B$. subtilis due to the appearance of the nymph stage and the general averages $1.45 \pm 0.32$ individual of moving stages was recorded. The results showed no significant differences between $P$. aeruginosa and $B$. subtilis in the general mean of moving stages comparing with that resulted when L. spaericus has applied. These results are in harmony with that proved by (Waked et al 2016). for the spraying technique with the bacterial, Pseudomonas fluorescens the highest mortality was recorded $100 \%$ and the lowest mortality was $68.75 \%, 58.75 \%$ and $16.25 \%$ for the dipping. The longevity was shorter than that of control with both methods, the female longevity averaged 10.32 and 17.04 days with the spraying and the dipping technique while, it was averaged 22.5 and 24.19 days in the control. Generally, the bacterial treatment reduced the number of the deposited eggs to the half when the spraying technique was applied.

Table 2. Average numbers of stages resulting from live adult females of Tetranychus urticae as affected by three bacterial strains by using spraying technique under laboratory conditions

\begin{tabular}{|c|c|c|c|c|c|c|c|}
\hline \multirow[b]{2}{*}{ Type of bacteria } & \multicolumn{4}{|c|}{ Mean Number of stages $T$. urticae } & \multirow{2}{*}{$\begin{array}{c}\text { General mean } \\
\text { of moving } \\
\text { stages } \pm S . E\end{array}$} & \multirow[b]{2}{*}{ F. Value } & \multirow[b]{2}{*}{ L.S. D } \\
\hline & $\begin{array}{c}\text { Con. } \\
\left.\text { (cfu. } \text { ml }^{-1}\right)\end{array}$ & $\begin{array}{l}\text { No. of } \\
\text { eggs }\end{array}$ & $\begin{array}{l}\text { No. of } \\
\text { larvae }\end{array}$ & $\begin{array}{c}\text { No. of } \\
\text { nymphs }\end{array}$ & & & \\
\hline Control & (water only) & 86.00 & 55.00 & 66.00 & $60.50 \pm 7.72 \mathrm{a}$ & 0.97 & 26.71 \\
\hline \multirow{4}{*}{$\begin{array}{c}\text { Pseudomonas } \\
\text { aeruginosa }\end{array}$} & $10^{1}$ & 1.67 & 1.33 & 0.00 & \multirow{4}{*}{$0.17 \pm 0.23 \mathrm{c}$} & \multirow{4}{*}{$1.00 * *$} & \multirow{4}{*}{1.06} \\
\hline & $10^{3}$ & 0.00 & 0.00 & 0.00 & & & \\
\hline & $10^{5}$ & 0.00 & 0.00 & 0.00 & & & \\
\hline & $10^{7}$ & 0.00 & 0.00 & 0.00 & & & \\
\hline \multirow{4}{*}{ Bacillus subtilis } & $10^{1}$ & 6.00 & 2.00 & 0.00 & \multirow{4}{*}{$0.42 \pm 0.35 \mathrm{c}$} & \multirow{4}{*}{$2.78 * *$} & \multirow{4}{*}{1.59} \\
\hline & $10^{3}$ & 3.33 & 1.34 & 0.00 & & & \\
\hline & $10^{5}$ & 0.00 & 0.00 & 0.00 & & & \\
\hline & $10^{7}$ & 0.00 & 0.00 & 0.00 & & & \\
\hline \multirow{4}{*}{$\begin{array}{l}\text { Lysinibacillus } \\
\text { spaericus }\end{array}$} & $10^{1}$ & 8.67 & 3.66 & 2.66 & \multirow{4}{*}{$1.45 \pm 0.32 \mathrm{~b}$} & \multirow{4}{*}{$1.62 *$} & \multirow{4}{*}{1.45} \\
\hline & $10^{3}$ & 4.67 & 2.33 & 2.00 & & & \\
\hline & $10^{5}$ & 2.00 & 1.00 & 0.00 & & & \\
\hline & $10^{7}$ & 0.00 & 0.00 & 0.00 & & & \\
\hline
\end{tabular}

Means with the same letter within each column are not significantly different at the $0.5 \%$ level (Duncan's multiple ranges clarifying by LSD test).

$*=\mathrm{P}<0.05, * *=\mathrm{P}<0.01$ 


\subsection{Effect of three bacterial strains against Tetranychus urticae by using the dipping technique}

Data given in Table 3 showed that, the highest mortality percentage of adult females, T. urticae by using dipping technique, was recorded $80 \%$ in case of $P$. aeruginosa after $72 \mathrm{~h}$ at concentration $\left(10^{7}\right)$. While the lowest mortality percentage was observed at the concentration $\left(10^{1}\right)$ and it was reached $25 \%$ after $24 \mathrm{~h}$, and the general mean recorded $54.58 \pm 1.71$. In $B$. subtilis, the highest mortality percentage of adult females $T$. urticae was recorded $70 \%$ at the concentration $\left(10^{7}\right)$ after $72 \mathrm{~h}$. While, at $10^{1}$ cfu. $\mathrm{ml}^{-1}$ lowest mortality percentage was recorded $(15 \%)$ after $24 \mathrm{~h}$ and the general mean recorded $41.25 \pm 2.08$. In L. spaericus the lowest concentration $\left(10^{1} \mathrm{cfu} . \mathrm{ml}^{-1}\right)$, the mortality percentage reached $5 \%$ after $24 \mathrm{~h}$, while at the highest concentration $\left(10^{7}\right)$ it reached $50 \%$ after $72 \mathrm{~h}$. The general mean was $27.50 \pm 1.61$ compared to that of the control $6.67 \pm 0.67$. The results showed highly significant differences between the three bacterial strains. These results resemble those obtained by (Vodovar et al 2006), who compared the mortality of the individuals with both spraying and dipping techniques, there was decreased in the mortality and more outspread after dipping application. This might be attributed to the body surface of T. urticae not being moisted and cells of Pseudomonas putida biotype B only being insert to the body surface indirectly and at low levels of fertilization, the lower levels of mortality spread over a long time. Also, (Aksoy et al 2008) recorded that, the spraying with the bacteria, Pseudomonas putida against T. urti$c a e$, was more effective, recorded highly significant differences than with the dipping techniques which showed $100 \%$ efficiency. Also, resulted in the fewest live eggs.

Data given in Table 4 conducted that, there was a slight increase in the average number of stages resulting from the adult living females after treatment with $P$. aeruginosa by using dipping technique, at the same four concentrations $10^{1}, 10^{3}, 10^{5}$ and $10^{7}$. The egg, larva and nymph stages were only observed and recorded in the lowest concentration $10^{1}$ and they were 5.00, 2.66 and 1.67 individual, respectively. While no stages were observed in the remaining concentrations of $10^{3,} 10^{5}$ and $10^{7}$ cfu. $\mathrm{ml}^{-1}$ and the general average for moving stages was $0.54 \pm 0.17$ individual. In case of $B$. subtilis, there was an increase in the mean number of the eggs, larvae and nymphs with each of the concentrations $10^{1}, 10^{3}$ and $10^{5} \mathrm{cfu}$. $\mathrm{ml}^{-1}$. Where at the lowest concentration $\left(10^{1}\right.$ cfu. $\mathrm{ml}^{-1}$ ), 10.67 individual were recorded, but at the concentration, $\left(10^{5} \mathrm{cfu} . \mathrm{ml}^{-1}\right)$ was 3.00 individual for egg stage. While for larva stage it was 5.00 individual at $\left(10^{1}\right)$ concentration, and 1.33 individual at $\left(10^{5}\right)$. As for the nymph stage in the same concentrations $\left(10^{1}\right)$ and $\left(10^{5}\right) 4.66$ and 1.66 individuals were recorded, while at the highest concentration $\left(10^{7}\right)$ no stages were recorded and the general average of moving stages reached $2.36 \pm 0.10$ individual compared with $P$. aeruginosa. In case of $L$. spaericus, there was a clear increase in the average number of stages resulting from the treated adult live females for each of the concentrations was observed, whereas, at the lowest concentration $\left(10^{1}\right)$, the average number recorded 19.00, 7.67 and 13.00 individual for the egg, larva and nymph take respectively. While at the highest concentration $\left(10^{7}\right)$ the numbers of stages recorded were 4.33, 1.00 and 2.00 individual respectively, and the general average calculated was $5.17 \pm 0.91$ individual. For control, recorded 105, 81 and 92 individuals for eggs, larvae and nymphs stage respectively, while the general mean of moving stages recorded was $86.50 \pm 2.13$. The results showed highly significant differences between the three bacterial strains in the general mean of moving stages. These results are in harmony with that of (David et al 2019) who revealed that, the application of $B$. subtilis could be considered as an alternative mean to control the two- spotted spider mite under field conditions. Also, (Qessaoui et al 2017) indicated that, the Pseudomonas fluorescens isolate Q036B is a promising candidate for biological control of all stages of (TSSM) and has 
Table 3. Mortality percentage of adult females Tetranychus urticae as affected by three bacterial strains by using dipping technique under laboratory conditions

\begin{tabular}{|c|c|c|c|c|c|c|c|}
\hline \multirow{2}{*}{ Type of bacteria } & \multirow{2}{*}{$\begin{array}{c}\text { Con. } \\
\left(\text { cfu. } \mathbf{m l}^{-1}\right)\end{array}$} & \multicolumn{3}{|c|}{\begin{tabular}{|c|}
$\%$ Mortality After detected \\
hours \\
\end{tabular}} & \multirow{2}{*}{$\begin{array}{l}\text { General mean } \\
\quad \pm S . \mathrm{E}\end{array}$} & \multirow[t]{2}{*}{ F. Value } & \multirow[t]{2}{*}{ L.S. D } \\
\hline & & $24 \mathrm{~h}$ & $48 \mathrm{~h}$ & $72 \mathrm{~h}$ & & & \\
\hline Control & water only & 5.00 & 5.00 & 10.00 & $6.67 \pm 0.67 \mathrm{~d}$ & $18.60 * *$ & 2.32 \\
\hline \multirow{4}{*}{$\begin{array}{l}\text { Pseudomonas } \\
\text { aeruginosa }\end{array}$} & $10^{1}$ & 25.00 & 40.00 & 55.00 & \multirow{5}{*}{$54.58 \pm 1.71 \mathrm{a}$} & \multirow{5}{*}{$90.18 * *$} & \multirow{5}{*}{5.94} \\
\hline & $10^{3}$ & 30.00 & 55.00 & 60.00 & & & \\
\hline & $10^{5}$ & 40.00 & 70.00 & 75.00 & & & \\
\hline & $10^{7}$ & 50.00 & 75.00 & 80.00 & & & \\
\hline Mean & & $36.25 \mathrm{c}$ & $60 \mathrm{~b}$ & $67.50 \mathrm{a}$ & & & \\
\hline \multirow{4}{*}{ Bacillus subtilis } & $10^{1}$ & 15.00 & 20.00 & 35.00 & \multirow{5}{*}{$41.25 \pm 2.08 \mathrm{~b}$} & \multirow{5}{*}{$18.00 * *$} & \multirow{5}{*}{8.16} \\
\hline & $10^{3}$ & 35.00 & 40.00 & 45.00 & & & \\
\hline & $10^{5}$ & 35.00 & 45.00 & 55.00 & & & \\
\hline & $10^{7}$ & 40.00 & 60.00 & 70.00 & & & \\
\hline Mean & & $31.25 \mathrm{c}$ & $41.25 \mathrm{~b}$ & $51.25 \mathrm{a}$ & & & \\
\hline \multirow{4}{*}{$\begin{array}{l}\text { Lysinibacillus } \\
\text { spaericus }\end{array}$} & $10^{1}$ & 5.00 & 15.00 & 25.00 & \multirow{5}{*}{$27.50 \pm 1.61 \mathrm{c}$} & \multirow{5}{*}{$72.00 * *$} & \multirow{5}{*}{4.08} \\
\hline & $10^{3}$ & 15.00 & 20.00 & 35.00 & & & \\
\hline & $10^{5}$ & 20.00 & 35.00 & 40.00 & & & \\
\hline & $10^{7}$ & 30.00 & 40.00 & 50.00 & & & \\
\hline Mean & & $17.50 \mathrm{c}$ & $27.50 \mathrm{~b}$ & $37.50 \mathrm{a}$ & & & \\
\hline
\end{tabular}

Means with the same letter within each column are not significantly different at the $0.5 \%$ level (Duncan's multiple ranges clarifying by LSD test).

$*=\mathrm{P}<0.05, * *=\mathrm{P}<0.01$

Table 4. Average numbers of stages resulting from live adult females of Tetranychus. urticae as affected by three bacterial strains by using dipping technique under laboratory conditions

\begin{tabular}{|c|c|c|c|c|c|c|c|}
\hline \multirow[b]{2}{*}{ Type of bacteria } & \multicolumn{4}{|c|}{ Mean Number of stages of $T$. urticae } & \multirow{2}{*}{$\begin{array}{c}\text { General } \\
\text { mean of } \\
\text { moving } \\
\text { stages } \pm \text { S.E }\end{array}$} & \multirow[b]{2}{*}{ F. Value } & \multirow[b]{2}{*}{ L.S.D } \\
\hline & $\begin{array}{c}\text { Con. } \\
\text { (cfu. } \mathbf{m l}^{-1} \text { ) }\end{array}$ & $\begin{array}{l}\text { No. of } \\
\text { eggs }\end{array}$ & $\begin{array}{l}\text { No. of } \\
\text { larvae }\end{array}$ & $\begin{array}{c}\text { No. of } \\
\text { nymphs }\end{array}$ & & & \\
\hline Control & water only & 105.00 & 81.00 & 92.00 & $86.50 \pm 2.13 \mathrm{a}$ & $18.03 * *$ & 7.35 \\
\hline \multirow{4}{*}{$\begin{array}{c}\text { Pseudomonas } \\
\text { aeruginosa }\end{array}$} & $10^{1}$ & 5.00 & 2.66 & 1.67 & \multirow{4}{*}{$0.54 \pm 0.17 \mathrm{~d}$} & \multirow{4}{*}{$1.00 * *$} & \multirow{4}{*}{0.79} \\
\hline & $10^{3}$ & 0.00 & 0.00 & 0.00 & & & \\
\hline & $10^{5}$ & 0.00 & 0.00 & 0.00 & & & \\
\hline & $10^{7}$ & 0.00 & 0.00 & 0.00 & & & \\
\hline \multirow{4}{*}{ Bacillus subtilis } & $10^{1}$ & 10.67 & 5.00 & 4.66 & \multirow{4}{*}{$2.36 \pm 0.10 \mathrm{c}$} & \multirow{4}{*}{0.13} & \multirow{4}{*}{0.46} \\
\hline & $10^{3}$ & 5.33 & 3.20 & 3.00 & & & \\
\hline & $10^{5}$ & 3.00 & 1.33 & 1.66 & & & \\
\hline & $10^{7}$ & 0.00 & 0.00 & 0.00 & & & \\
\hline \multirow{4}{*}{ Lysinibacillus spaericus } & $10^{1}$ & 19.00 & 7.67 & 13.00 & \multirow{4}{*}{$5.17 \pm 0.91 \mathrm{~b}$} & \multirow{4}{*}{1.69} & \multirow{4}{*}{4.08} \\
\hline & $10^{3}$ & 10.00 & 6.33 & 5.67 & & & \\
\hline & $10^{5}$ & 7.33 & 2.33 & 3.33 & & & \\
\hline & $10^{7}$ & 4.33 & 1.00 & 2.00 & & & \\
\hline
\end{tabular}

Means with the same letter within each column are not significantly different at the $0.5 \%$ level (Duncan's multiple ranges clarifying by LSD test).

$*=\mathrm{P}<0.05, * *=\mathrm{P}<0.01$ 
a potential to contribute to an integrated pest management program to control this important pest.

3.3 Description of the symptoms that appeared on the individuals of adult females of Tetranychus urticae after treatment with the three bacterial strains under laboratory conditions

(A) Adult females of T. urticae begin to die after 24 hours, and then a swelling of the body occurred to the body Fig 1 .

(B) Causing an explosion of the contents of the body, and liquid comes out like bloody poisoning

(C) Dryness of mites occurred and the body's appendages were protruded forward to the podosoma region (Propodosoma + Metapodosoma).

(D) The body of adult females of T. urticae becomes a dry mummy on the leaf surface of the plant.

Results of symptoms that appeared on individuals of adult females after treatment with the tested bacteria were in harmony with that of (Mahmoud et al 2020) who proved that, diagnostic symptoms considered as a common property of the bacterial infection of mites were recorded distinct color changes (dark brown color with a black tinge), degeneration of internal tissues, discontinuation of feeding, inability to move, weakening of the outer shield, the females failed to oviposit, excretion of diarrhoea-like faeces, occasionally causing mites to turn into glued to the substrate, vomiting and cadavers becoming black due to the bacterial infection. Also, (Wilson et al 2002) reported that, the bacterial hemolysins attacked the blood cell membranes and causes rupturing and body swelling. These hemolysins may also be involved in the pathogenicity of the three bacterial species on T. urticae, especially resulted to the rapid mortality. Bacterial pathogens invade their hosts through the mouth and the alimentary canal. Less often, they enter through peritremes and wounds in the integument (Poinar and Poinar 1998). He showed that, the bacterial infections perhaps classified as toxaemia, when bacteria are confined in the alimentary canal where they produce toxins causes septicaemia and when bacteria multiply in the hemocoel, and the mites will be killed (Tanada and Kaya 1993) and (Raaijmakers et al 2002), they indicated that, pathogenic bacteria Pseudomonas affect the cell surface of the host, this adhesion of bacteria may increase the entry of proteases, chitinases and lipases through the epidermis, stigmata and body openings of $T$. urticae, which can lead to rapidly death of the mites.

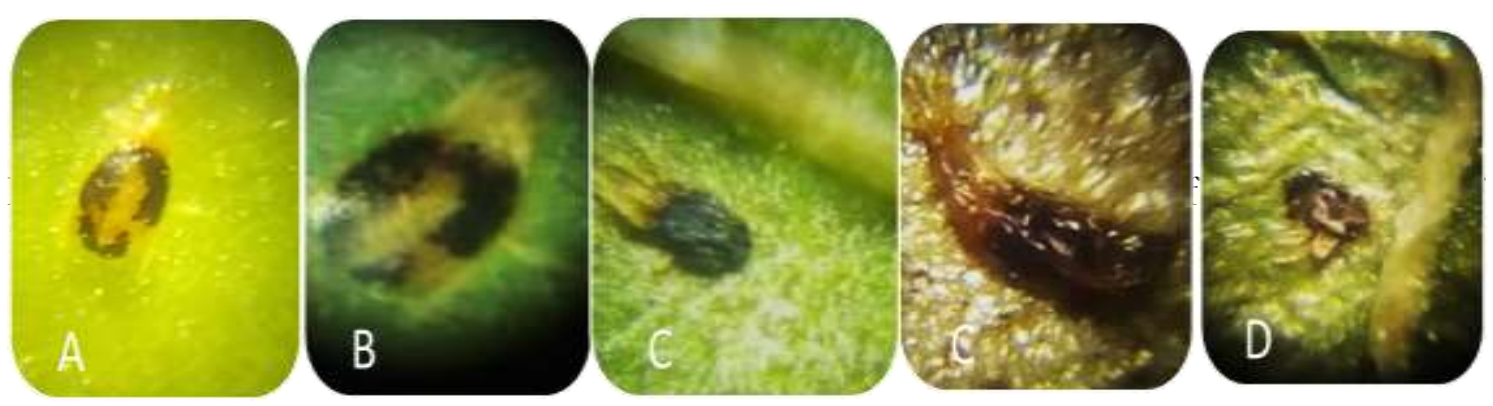

Fig 1. Description of the symptoms that appeared on individuals of adult females of Tetranychus. urticae after treatment with the three bacterial strains 


\section{Conclusion}

The mention scientific names of the bacteria cleared high mortality percentage varying according to concentration and according to the method the of application, either through spraying or dipping techniques, the spraying technique revealed a significant difference and increase in the mortality percentage compared to that through the dipping technique, $P$. aeruginosa was the most effective at the concentration $\left(10^{7} \mathrm{cfu} . \mathrm{ml}^{-1}\right)$, using the spraying technique. Also, as a result of the exposure to bacteria there were symptoms of death beginning with swelling of the body and ended with complete dryness have been evolved.

\section{Acknowledgments}

This work was done in the Acarology Lab., Faculty of Agriculture, Ain Shams University, Cairo, Egypt, with personal funding.

\section{References}

Abbott, WS (1925) A method of computing the effectiveness of an insecticide. J Econ Entomol 18, 265-267.

Abou Zaid, WR; Mowafy, AM; ElDemerdash, A (2018) The effect of Bacillus species on the response of common bean to Tetranychus urticae (Acari: Tetranychidae) infestation. Egypt. J Plant Prot Res Inst 1, 122130.

Aksoy, MH; Ozman-Sullivan, SK; Ocal, H; Celik, N; Sullivan, GT (2008) The effects of Pseudomonas putida biotype $\mathrm{B}$ on Tetranychus urticae (Acari: Tetranychidae). Exp Appl Acarol 46, 223-230.

Arzanlou, M; Mousavi, S; Bakhshi, M; Khakvar, R; Bandehagh, A (2016) Inhibitory effects of antagonistic bacteria inhabiting the rhizosphere of the sugar beet plants, on Cercospora beticola Sacc., the causal agent of Cercospora leaf spot disease on sugar beet. Journal of Plant Protection Research 56, 6-14.
Carey, JR; Bradley, JW (1982) Developmental rates, vital schedules, sex-ratios and life tables for Tetranychus urticae, T. turkestani and T. pacificus (Acarina: Tetranychidae) on cotton. Acarologia 23, 333-345.

David, ML; Dobronski-Arcos, J; VásquezFreytez, C; Frutos-Pinto, V; Paredes-Carreño, S (2019) Control de Tetranychus urticae Koch (Acari: Teteranychidae) Con Bacillus subtilis En hojas de Fresa (Fragaria vesca). Agronomía Costarricense 43, 125-133.

Davis, RW; Botstein, D; Rotho, JR (1980) Transfection of DNA in Bacterial Genetics: A Manual for Genetic Engineering Advanced Bacterial Genetic. Cold Spring Harbor laboratory cold spring harbor, New York., 67, 134137.

Duncan, DB (1955) Multiple Range and Multiple F Tests. Biometrics 11, 1-14.

Fiedler, Z (2012) Interaction between beneficial organisms in control of spider mite Tetranychus urticae (Koch.). Journal of Plant Protection Research 52, 226-229.

Li, XY; Munir, S1; Cui, WY; He, PJ; Yang, J; He, PF; Wu, YX; Wang, Y H; Hw, YQ (2019) Genome Sequence of Bacillus Velezensis W1, A strain with Strong Acaricidal Activity against Two-Spotted Spider Mite, (Tetranychus urticae). Applied Ecology and Environmental Research 17, 2689-2699.

Mahmoud, M Al-Azzazy; Abdullah, S Alsohima; Carl E Yoderc (2020) Biological effects of three bacterial species on Tetranychus urticae (Acari: Tetranychidae) infesting eggplant under laboratory and greenhouse conditions. Acarologia 60, 587-594.

Muir, RC; Cranham, JE (1979) Resistance to pesticides in damson-hop aphid and red spider mite on English hops. Proc Br Crop Prot Conf 1,161-167.

Park, YL; Lee, JH (2002) Leaf cell and tissue damage of cucumber caused by two spotted spider mite (Acari: Tetranychidae). Journal of Economic Entomology 5, 952-957. 
Poinar, R; Poinar, G (1998) Parasites and pathogens of mites. Annu Rev Entomol 43, 449469.

Pritam, S; Clare, GK (1993) A method for continuous production of diapausing two-spotted mite in the laboratory. The Horticulture and Food Research Institute of New Zealand, vol.16.

Qessaoui, R; Bouharroud, R; Amarraque, A; Ajerrar, A; Mayad, E; Chebli, B; Dadi, M; Elaini, R; El-Filali, F; Walters, AS (2017) Ecological applications of Pseudomonas as a biopesticide to control two-spotted mite Tetranychus urticae: chitinase and HCN production. Journal of Plant Protection Research $57 \mathrm{p}$.

Raaijmakers, JM; Vlami, M; De Souza, JT (2002) Antibiotic production by bacterial biocontrol agents. Antonie Leeuwenhoek Int J G 81, 537-547.

Rathore, AS; Gupta, RD (2015) Chitinases from bacteria to human: properties, applications, and future perspectives. Enzyme Research pp 1-8.

Roobakkumar, A; Babu, A; Kumar, DV; Sarkar, S (2011) Pseudomonas fluorescens as an efficient entomopathogen against Oligonychus coffeae (Nietner) (Acari: Tetranychidae) infesting tea. Journal of Entomology and Nematology 3, 73-77.

Ruiu, L (2015) Insect pathogenic bacteria in integrated pest management. Insects 6, 352367.
Soliman, M Gaziea; Hoda, HA; Shadia, MA; Ghada, ME (2019) In vitro evaluation of some isolated bacteria against the plant parasite nematode Meloidogyne incognita. Bulletin of the National Research Centre 43, 171.

Tanada, Y; Kaya, HK (1993) Insect Pathology. Academic Press, San Diego, Publisher. pp 666.

Steel, R.G; Torrie, JH (1984) Participles and Procedures of Statistics McGraw- Hill Co., Singapore, 2nd Ed. 4thPrintin.

Veloorvalappil, NJ; Smitha, RB; Benjamin, S (2013) An Overview on the Crystal Toxins from Bacillus thuringiensis. Advances in $\mathrm{Mi}$ crobiology 3, 462-472.

Vodovar, N; Vallenet, D; Cruveiller, S; Rouy, Z; Barbe, V; Acosta, C; Cattolico, L; Jubin, C; Lajus, A; Segurens, B; Vacherie, B; Wincker, P; Weissenbach, J; Lemaitre, B; Me'digue, C; Boccard, F (2006) Complete genome sequence of the entomopathogenic and metabolically versatile soil bacterium Pseudomonas entomophila. Nat Biotechnol 24, 673-679.

Waked, D A; Eleawa, M; Salama, A (2016) Using Pseudomonas Fluorescens as Microbial Biocontrol Agent against The Spider Mite, $T e$ teranychus Cucurbitacearum (SAYED) (Acari: Tetranychidae). Egypt J Agric Res, 94, 625.

Wilson, M; McNab, R; Henderson, B (2002) Bacterial Disease Mechanisms: An Introduction to Cellular Microbiology. Cambridge University Press, UK, Publisher pp 656. 


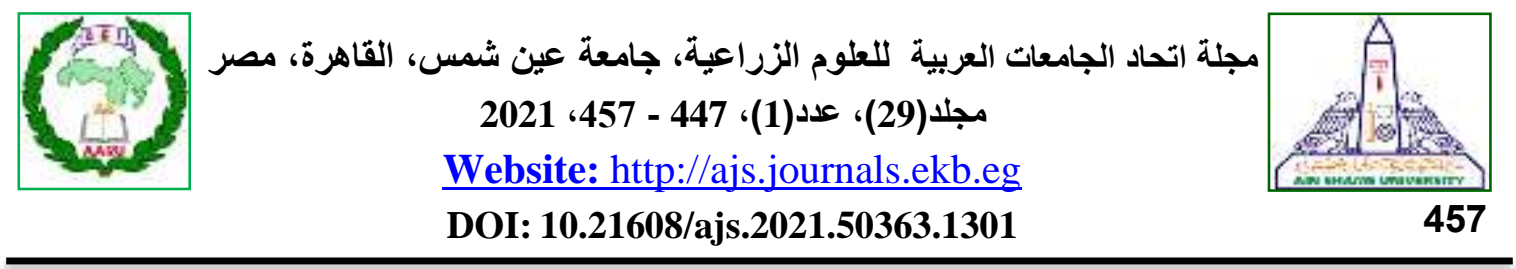

كفاءة ثلاثة أنواع من السلالات البكتيرية ضد Tetranychus urticae Koch تحت الظروف المعملية (Acari: Tetranychidae)

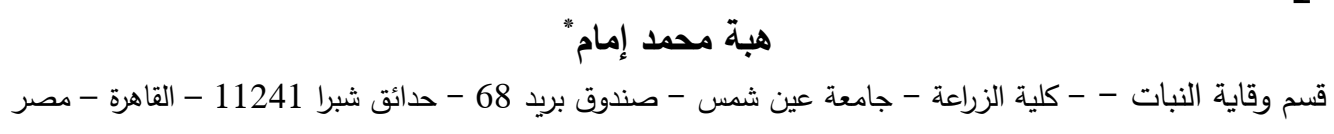

[31]

*Corresponding author: Hebasoliman@agr.asu.edu.eg

Received 3 December, 2020

Accepted 28 February, 2021

B. subtilis

لإناث الأكاروس Bubtili

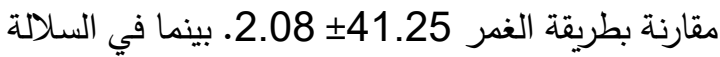

L. spaericus

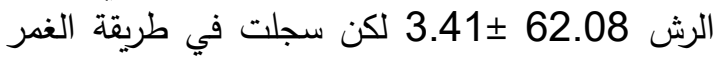

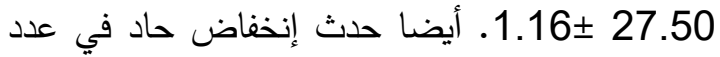

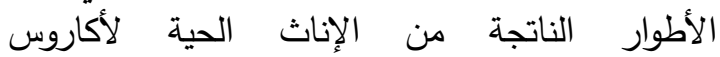

عند إستخدام T. articae

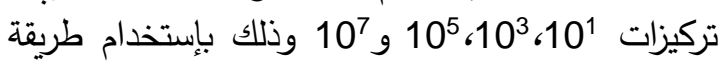

الرش، ولوحظ أيضا توقف دورة الحياة عند طور اليرقة

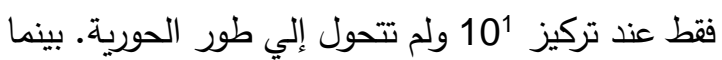

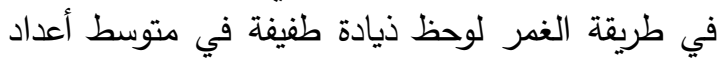

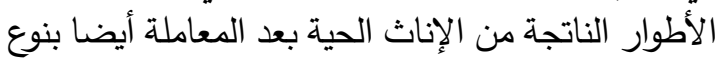

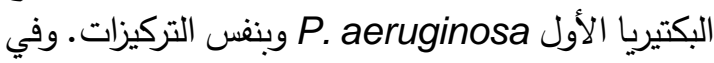

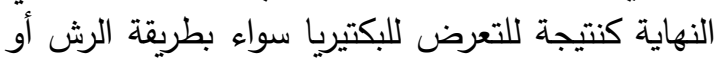

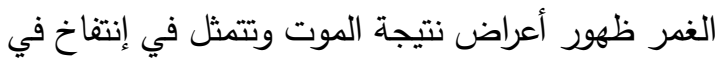

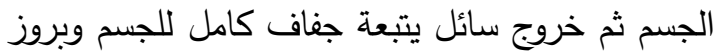

الأطراف للأمام لكل من منطقة الأرجل الأمامية

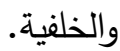

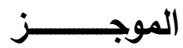

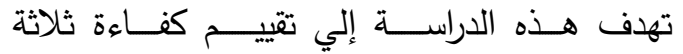

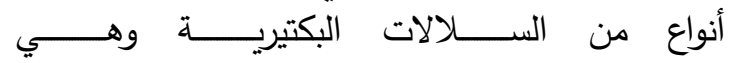

Bacillus ‘Pseudomonas aeruginosa ضysinibacillus spaericus g subtilis الإناث الكاملة لأكاروس العنكبوت الأحمر ذي البقعتين Tetranychus urticae

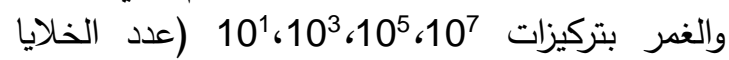

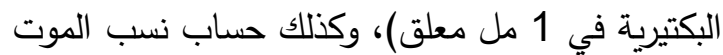

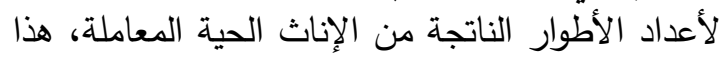

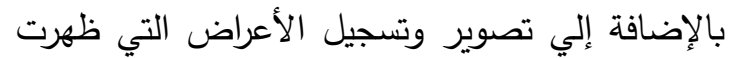

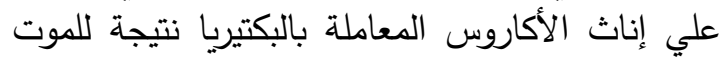

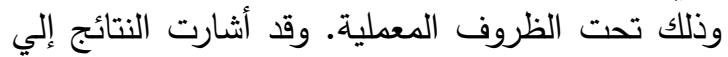

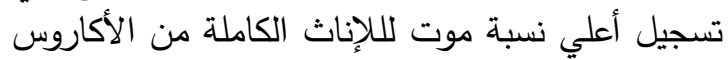

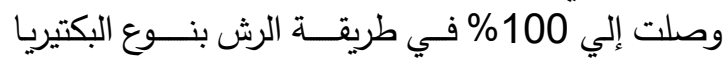
(107cfu. بعد 72 ساعة بتركيز P. aeruginosa

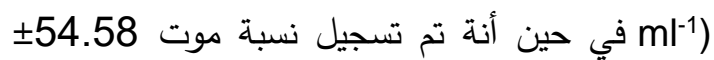
1.71 بإستخدام طريقة الغمر. أما في في السلالة 